\title{
Patients participation on Brazilian Health technology Assessment Process
}

\author{
Marisa Santos* and Viviane Gomes Parreira Dutra \\ National Institute of Cardiology, Rio de Janeiro, Brazil
}

Submission: June 01, 2018; Published: June 07, 2018

*Corresponding author: Marisa Santos, National Institute of Cardiology, Rio de Janeiro, Brazil, Email: marisaccih@gmail.com

\section{Brazilian Health Technology Assessment (HTA)}

Brazilian public decision about incorporation, exclusion or change of new medicines, devices, procedures and in the constitution or modification of clinical protocols or therapeutic guidelines is centralized in the National Commission for incorporation of Health Technologies (CONITEC) linked to Ministry of Health [1,2]. After a demand, usually, from industries, an external report was elaborated including evidence, economic studies, and additional issues as logistic problems and training needs. The initial recommendation on incorporation or exclusion of technology is issued by the Plenary, which consists of representatives of the Ministry of Health and its regulatory agencies, the Federal Council of Medicine (CFM) and the National Health Council (CNS). The participation of civil society is initially given by representation of members of these two councils [3]. A preliminary decision was followed by a simplified report for lay people and a public consultation the website (http://conitec.gov. $\mathrm{br} /$ index.php/participacao-social). The final decision includes reviewing of public consultation information (Figure 1).

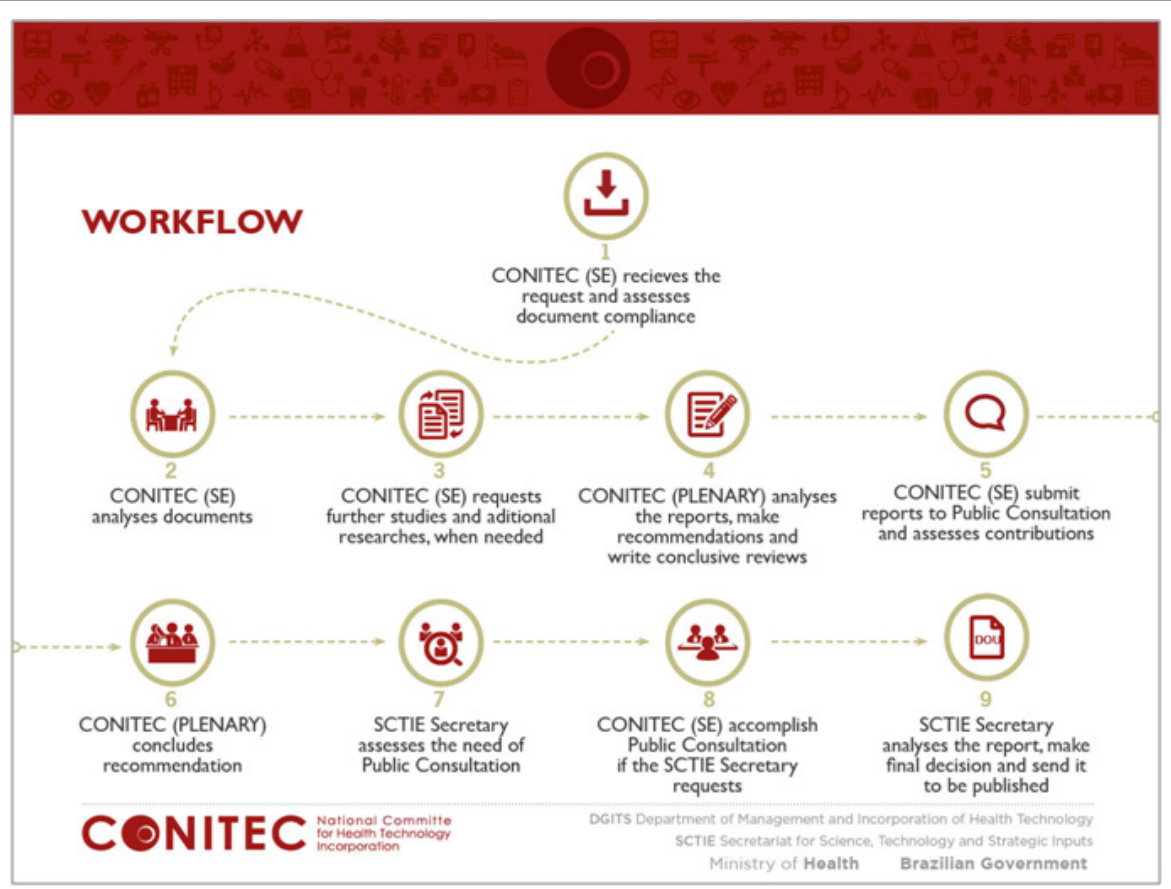

Figure 1: Workflow of Health technology Assessment in Brazil.

\section{Public Consultation}

The purpose of the public consultation is to promote the participation of society in the decision-making process for the inclusion or exclusion of medicines and other technologies in the Brazilian Health System (SUS), thus broadening the discussion on the formulation and definition of public policies in Brazil [4]. A question arises about content and relevance of public consultation contribution on HTA process. Since 2015, CONITEC has initiated the development of surveys to analyze patients' preferences for treatments. They included the participation of 
society in the elaboration of Clinical Protocols and Therapeutic Guidelines (PDCT), but this type of survey is not yet a real influence in the proccess of building the report for the CONITEC's Plenary [5].

For this evaluation, six public consultations assessed by National Institute of Cardiology between January 2013 and December 2017 were reviewed. The data source used was the form of scientific contributions and the form with contributions from patients or carriers, both are publicly accessible on the CONITEC website (http://conitec.gov.br/ index.php/participacao-social). The chosen consultations were: Icatibant for hereditary angioedema, Targeted intraoperative radiotherapy for breast cancer, Beta-interferon (IFN-b-1a-IM) disinvestment for multiple sclerosis6, Biocellulose dressings for venous ulcers, Transcatheter aortic valve implantation for aortic stenosis and Intensity-modulated radiotherapy for head and neck cancer (Table 1).

Table 1: Selected characteristics of the demands assessed by National Institute of Cardiology, 2013 to 2017.

\begin{tabular}{|c|c|c|c|c|c|c|c|c|}
\hline Demand & $\begin{array}{l}\text { Technology } \\
\text { Type }\end{array}$ & Year & $\begin{array}{c}\text { Number } \\
\text { of Public } \\
\text { Consultations }\end{array}$ & Patients & oS & $\begin{array}{c}\text { Preliminary } \\
\text { Recommendation }\end{array}$ & $\begin{array}{l}\text { Contributions Received } \\
\text { in Public Consultations }\end{array}$ & $\begin{array}{c}\text { Final } \\
\text { Recommendation } \\
\text { of the Commitee }\end{array}$ \\
\hline $\begin{array}{l}\text { Icatibant for } \\
\text { hereditary } \\
\text { angioedema }\end{array}$ & Medicine & 2015 & 109 & 70 & 39 & No Incorporation & $\begin{array}{l}\text { Technical contributions: } \\
\text { New search in the } \\
\text { literature, being located } \\
\text { evidence for pregnant } \\
\text { women; questions about } \\
\text { inclusion of productivity } \\
\text { losses: (not included - } \\
\text { SUS perspective) }\end{array}$ & No Incorporation \\
\hline $\begin{array}{l}\text { Targeted } \\
\text { intraoperative } \\
\text { radiotherapy for } \\
\text { breast cancer }\end{array}$ & Device & 2016 & 3 & 0 & 3 & No Incorporation & $\begin{array}{l}\text { Technical contributions: } \\
\text { Update of Oncology } \\
\text { Technical Basis Manual } \\
\text { (accepted) }\end{array}$ & No Incorporation \\
\hline $\begin{array}{l}\text { Betainterferone } \\
\text { for multiple } \\
\text { sclerosis }\end{array}$ & Medicine & 2016 & 3.064 & 3064 & 0 & No Incorporation & $\begin{array}{l}\text { Patients contributions: } \\
\text { Contributions with } \\
\text { identical excerpts ("copy } \\
\text { and paste") Popular } \\
\text { commotion: even with } \\
\text { the prescription kept } \\
\text { for patients who use } \\
\text { medicine }\end{array}$ & Disinvestment \\
\hline $\begin{array}{l}\text { Biocelulose } \\
\text { dressings for } \\
\text { chronic wounds }\end{array}$ & Device & 2017 & 24 & 12 & 12 & No Incorporation & $\begin{array}{l}\text { Technical and patients } \\
\text { contributions: They } \\
\text { disagreed with } \\
\text { the preliminary } \\
\text { recommendation } \\
\text { of restricting the } \\
\text { population, but without } \\
\text { sending any new data. }\end{array}$ & $\begin{array}{l}\text { Incorporate only } \\
\text { for venous ulcers } \\
\text { (no evidence for } \\
\text { burns) }\end{array}$ \\
\hline $\begin{array}{l}\text { TAVI for aortic } \\
\text { stenosis }\end{array}$ & Device & 2013 & 12 & 0 & 12 & No Incorporation & $\begin{array}{l}\text { Technical contributions: } \\
\text { Recalculating budgetary } \\
\text { impact and new search } \\
\text { in literature (accept) }\end{array}$ & No Incorporation \\
\hline $\begin{array}{l}\text { IMRT for head } \\
\text { and neck cancer }\end{array}$ & Device & 2017 & 138 & 10 & 128 & No Incorporation & $\begin{array}{l}\text { Technical contributions: } \\
\text { New literature } \\
\text { search, no evidence } \\
\text { to change preliminary } \\
\text { recommendation; } \\
\text { Inclusion of the costs } \\
\text { of complications - no } \\
\text { data available; Retrieved } \\
\text { comments on Shielding - } \\
\text { there is already a margin } \\
\text { of safety in the current } \\
\text { shielding; Rewrite } \\
\text { included study for } \\
\text { effectiveness calculations } \\
\text { (some contributions } \\
\text { were accepted) }\end{array}$ & No Incorporation \\
\hline
\end{tabular}


Of the six public consultations selected $4(67 \%)$ were requests for incorporation of the device. The contributions received in the public consultations of medicines with an unfavorable recommendation ranged from 109 to 3,064 (median of 1,586). Beta-interferon for the treatment of Multiple Sclerosis received more than 3.000 contributions. Of these contributions, more than $80 \%$ had identical parts, of the type "copy and paste," probable because of the idea that the number of contributions could influence the alteration of the final recommendation.

Devices presented a median of 18 contributions, varying from 3 to 138. Of the four devices evaluated, the targeted intraoperative radiotherapy for breast cancer and Transcatheter aortic valve implantation did not receive any contributions from the patients. It is explained by the fact that very complex subjects cannot be evaluated by individuals who do not have scientific knowledge or any training on HTA. All the technical contributions sent in the public consultation of the targeted intra operative radiotherapy for breast cancer were in agreement with the preliminary recommendations of the Plenary that they contributed to the updating of the Manual of Technical Basis of Oncology of the Brazilian Health System (SUS). After the public consultation, there was no change between the initial and final recommendations in any of the six demands analyzed. In the case beta-interferon disinvestment, the preliminary recommendation was for disinvestment was based on indirect comparison and real world evidence studies, justified by low efficacy and a higher risk of treatment failure. After the public consultation, 39 technical contributions were received with new information on the safety of the drug for pregnant women. Thus, a new search was done in the literature, which did not evidence these findings. The disinvestment recommendation was maintained by the committee but was reverted by a political decision. In the case of intense modulated radiotherapy for head and neck cancer, 128 technical contributions were sent against the recommendation of non-incorporation, but in none of them was scientific evidence that could support the request.

\section{Conclusion}

The results show that public consultation is not the best instrument for society's contribution to the health technology assessment process in the Brazilian Health System (SUS). Although the process is broad and inexpensive, it is limited and generates few possibilities for change, taking into account the number of contributions sent versus the quality of their content. The process may be strongly influenced by marketing. The very complex issues have little involvement of patients.

In this way, the submission of demand to the public consultation should be instituted as a first step to receive contributions and suggestions, making the decision-making process for the incorporation of technologies more democratic for Brazilian society. Thus, it is necessary to develop strategies for participation and effective social control, aiming to bring patients' perspectives closer to decision makers in health systems. Some possibilities are preference studies as a discrete choice experiment, focal groups or inclusion of patient representatives in the Committee. Other suggestion is to train a group of patients to effective participate in the decision process.

\section{Refernces}

1. Lei no 12.401 , de 28 de abril de 2011. Altera a Lei $\mathrm{n}^{\circ} 8.080$, de 19 de setembro de 1990, para dispor sobre a assistência terapêutica e a incorporação de tecnologia em saúde no âmbito do Sistema Único de Saúde, Brasil.

2. (2011) Dispõe sobre a Comissão Nacional de Incorporação de tecnologias no Sistema Único de Saúde e sobre o processo administrativo para incorporação, exclusão e alteração de tecnologias em saúde pelo Sistema Único de Saúde, e dá outras providências, Brasil.

3. Caetano R (2017) Incorporation of new medicines by the National Commission for Incorporation of Technologies, 2012 to June 2016. Ciência \& Saúde Coletiva 22(8): 2513-2525.

4. (2012) Aprova o Regimento Interno da Comissão Nacional de Incorporação de tecnologias no Sistema Único de Saúde (CONITEC), Brasil.

5. Lemos LLP, Guerra Junior AA, Santos M, Magliano C, Diniz I, et al (2018) The Assessment for Disinvestment of Intramuscular Interferon Beta for Relapsing Remitting Multiple Sclerosis in Brazil. Pharmaco Economics 36(2): 161-173. 